\title{
USING IEPC STRATEGY TO IMPROVE STUDENTS' READING COMPREHENSION AT GRADE VIII.4 OF SMP NEGERI 3 PEKANBARU
}

\author{
Liya Astarilla Dede Warman \\ STMIK AMIK Riau \\ email: liya.astarilla@gmail.com
}

\begin{abstract}
The purposes of this research are to describe and explain to what extent IEPC strategy could improve students' reading comprehension at grade VIII.4 of SMP Negeri 3 Pekanbaru and the factors that influenced the change of their reading comprehension by using IEPC strategy at grade VIII.4 of SMP Negeri 3 Pekanbaru. This research is classroom action research, every cycle consisted of four fundamental aspects namely, planning, action, observation, and reflection. This research consisted of three cycle, where in each cycle consisted of fourmeetings. The four meetings in one cycle involving three meetings for teaching reading by using IEPC strategy and one meeting for post-test at the end of every cycle.The participants of this research were the researcher, a collaborator and the students of grade VIII.4 of SMP Negeri 3 Pekanbaru totalling 40 students. The instruments of this research were reading comprehension test, an observation sheet, field note and interview.There were two findings of this research: (1) IEPC strategy could improve the students' reading comprehension; (2) Teaching material and media, class activity, class management, and teacher's approach were the factors that could influence the change of students' reading comprehension.
\end{abstract}

Keywords: reading comprehension, IEPC strategy, factors.

\section{PENGGUNAAN STRATEGI IEPC UNTUK MENINGKATKAN KEMAMPUAN MEMBACA SISWA/SISWI KELAS VIII.4 DI SMP NEGERI 3 PEKANBARU}

\begin{abstract}
Abstrak
Tujuan penelitian ini adalah untuk menjelaskan sejauh mana IEPC strategi meningkatkan pemahaman membaca teks pada siswa kelas VIII.4 di SMP Negeri 3 Pekanbaru dan juga menjelaskan faktor-faktor apa saja yang mempengaruhi perubahan pemahaman membaca mereka. Penelitian ini merupakan penelitian tindakan kelas, dimana setiap satu siklus terdiri dari empat aspek penting yaitu perencanaan, pemberian tindakan, pengamatan, dan refleksi.Penelitian ini terdiri dari tiga siklus, dimana pada masing-masing siklus terdiri dari empat kali pertemuan. Empat pertemuan pada satu siklus meliputi tiga pertemuan untuk pembelajaran membaca teks dengan menggunakan IEPC strategi dan satu pertemuan untuk tes pemahaman membaca teks.Partisipan dalam penelitian ini adalah peneliti, seorang kolaborator, dan siswa kelas VIII.4 di SMP Negeri 3 Pekanbaru yang berjumlah 40 orang. Instrumen yang digunakan dalam penelitian ini adalah tes pemahaman, lembar observasi, catatan lapangan, dan wawancara. Ada dua temuan pada penelitian ini yaitu: (1) IEPC strategi dapat meningkatkan nilai pemahaman membaca teks; (2) bahan dan media ajar, aktifitas kelas, manajemen kelas, pendekatan guru adalah beberapa faktor yang dapat mempengaruhi perubahan pemahaman membaca pada siswa.
\end{abstract}

Kata Kunci: MemahamiBacaan,Strategi IEPC, Faktor. 


\section{INTRODUCTION}

Reading is one of the skills that the students should master in learning English in order to get information from the English materials. The aim of teaching reading is to make students able to read English texts effectively and efficiently. They do not only have to understand the structure of the texts explicitly but more importantly they must comprehend the meaning implicitly.

According to School-Based Curriculum (KTSP), the aim of teaching English is to develop the students' communication skills in listening, writing, reading and speaking. Teaching reading has equal duration to other English skills, namely listening, writing and speaking. Therefore, the teacher should apply appropriate reading strategy to increase the students' ability in comprehending reading text. Reading should be taught in effective and efficient way by using the appropriate strategy. The strategy used by the teacher should be appropriate to the students' level so that they can apply the strategy and comprehend English text well. There are some genres of texts that are taught for grade VIII of SMP students they are descriptive, narrative, recount text. Descriptive text is a text that describes a particular person, thing or place. Narrative text is a text that tells a story, a fictive or non-fictive. Recount text is a text that retells events for informing or entertaining.

Based on the researcher's experience and observation at class VIII.4 of SMP Negeri 3 Pekanbaru, it was discovered that the students had low achievement in reading comprehension tests, most of them had problems in comprehending texts. The researcher found that some students still have problems in finding information in the texts and they also did not know the components of reading comprehension, namely; finding factual information, finding main ideas, finding the meaning of vocabulary in context, identifying references, and making inferences. It was known based on the result of the test given by the teacher. The number of students who joined the test was 40 students. The result of the test showed that the average score was only 56.87 , while the minimum criteria of achievement is 70 . In other words, the result of the test shows that the students had not achieved the minimum criteria of achievement (KKM) of English subject at SMP Negeri 3 Pekanbaru.

Ahuja and Ahuja (2001:5) state, reading is both a sensory and mental process. It means that the readers use their eyes and their mind in reading. The eyes receive messages and the brain has to work out the significance of this messages. It requires the people to read for meaning. They do not only read the text but also understand the meaning of written text being read.According to Grabe and Sttaler (2002:18) reading is also interactive in the sense that linguistic information from the text interacts with information activated by the reader from long-term memory, as background knowledge. It can be concluded that reading is an interactive and a thinking process of transferring printed letters into meaning in order to communicate certain message between the writer and the reader. In reading actively a reader brings her or his background knowledge, emotion, and experience to construct his or her idea in understanding the meaning of the text.

Burnes and Page (1991:46) state that comprehension is the process where background knowledge or the world knowledge of the reader interacts with

Using IEPC Strategy to Improve Students'

Reading Comprehension at Grade VIII.4 of

SMP Negeri 3 Pekanbaru 
the message encoded in the text to get understanding of an author's message. Then, Neufeld (2005:302) states that comprehension is the process of constructing a supportable understanding of a text. He added comprehension involves two important features: being actively involved with the text and using appropriate background knowledge to interpret the text. It is also supported by Ahuja and Ahuja (2001:10) state that comprehension is the product of reconstructing the facts within the nervous system of the reader. It means that the reader will reconstruct her or his background knowledge in understanding the text.

Devine (1987:7) argues that reading comprehension is a process of activating the prior knowledge of the reader which cooperates with his appropriate cognitive skills and reasoning ability to find out the concept from a printed text. In these words, the reader must be able to understand, to interpret and to select actual information from text. Burnes and Page (1991:46) state that reading comprehension is a reading, thinking activity and as such relies for it success upon the level of intelligence of the reader. It means that in reading comprehension, the readers have to involve their intelligence because it can influence to their ability in comprehending what they read. Diptodadi (1992:85) states that comprehension can be defined as an active integrative process in which readers try to relate what they read with what they already know about the topic. This definition means that the information from the text integrated with the readers' comprehension process. The readers can use their prior knowledge to guess about the materials that they will read, so it will give contribution to the readers' achievement in reading. At least, it can give general description about something on the texts or reading materials. According to Kendeou et al (2007), reading comprehension can be defined as constructing a mental representation of textual information and its interpretation or in other words getting meaning from written words, sentences and texts. It means that the reader will use their mental images in reading and interpreting the meaning of the text.

Reading comprehension as discussed above indicates that it is a complex process by which a reader tries to reconstruct a message encoded in graphic language by a writer. It is an interaction between reader and author. In conclusion, comprehension will occur if the textual information actives expectation about what is in the text and the interactive process will continue until the reader is satisfied with the match between background knowledge.

Based on the interviewed conducted towards the students, the above phenomenon have been influenced by some factors. First, the students were not interested in reading because they did not know how to comprehend the texts. Consequently, they had low motivation in learning reading. The second factors is the students' lack of vocabulary mastery. So, it was difficult for them to comprehend the texts. Third, the technique and method used by the teacher at SMP Negeri 3 Pekanbaru in teaching reading were often not effective. The teacher usually use discussion technique and grammar translation method that is explaining everything to students by translating each sentence, word by word rather than helping students to read by promoting thinking about its meaning. For example, the students are asked to read aloud sentence by sentence or paragraph by

Using IEPC Strategy to Improve Students'

Reading Comprehension at Grade VIII.4 of

SMP Negeri 3 Pekanbaru 
paragraph and then answer the teacher's questions or work with the teacher to translate the text. This way of teaching reading is considered a passive language process because there is only little interaction between the readers and the text. This way of teaching reading was less effective in teaching reading because it did not encourage and motivate the students to improve their comprehension.

Realizing the phenomenon above, appropriate reading techniques in teaching reading should be implemented in the classroom because, teaching technique could give great effect on the students' success in reading texts. The technique used by the teacher should be appropriate to the students' comprehension level. The technique that might be implemented is IEPC strategy that is suggested by Wood (2002). IEPC stands for Imagine, Elaborate, Predict, and Confirm. The IEPC strategy helps students become active participants by using what they already know to understand new information The goal of the strategy is to help the students in comprehending reading text. Each phase of IEPC strategy designed to improve the teaching and learning process which is also aimed to improve the students' reading comprehension through prereading, reading, and post-reading stages of an instructional lesson.

The first phase of IEPC strategy is imagine. In this phase, the students have to try creating mental images before reading the text. So, it can help them in comprehending reading text. Gambrell and Bales (1986) state that mental imagery plays an important role in the dynamic, interactive process of reading. It means that by imagining which incorporates the activation of the five senses: seeing, hearing, smelling, tasting, and physically or emotionally feeling can

J-SHMIC, Vol 3, No 2, August 2016 help the readers in comprehending the texts.

Elaborate refers to the practice of forming connections between previously learned information and new content through imagery, visualization, analogies, descriptions and details. It means that the students use their previous knowledge in making image and add details about the topic so that it can develop their understanding about the text. Anderson and Armbruster (1990) state that elaboration refers to the practice of forming connections between previously learned information and new content through imagery and visualization, analogies, descriptions, and details. According to Hartman et. al, in Wood (2004:4), the use of elaboration can develop understanding by getting students to extend and modify their verbalization during reading. Then, Cooper in Wood (2002:1) states that elaboration is the practice of forming connections between previously learned information and new content through imagery, visualization, analogies, descriptions and details. It means that the students use their previous knowledge in making image and add details about the topic so that it can develop their understanding about the text. It is also supported by Brooks, et al in Burnes (1991:47), he states that in order to understand and remember what is read, students must be able to relate the new information to previous knowledge and this is obviously a complicated process entailing a number of transformations in the written material to match it with previous knowledge. So, it can help the reader to comprehend reading material easier.

The third phase is predict. In this phase, the students have to make their prediction about the text they are going

Using IEPC Strategy to Improve Students'

Reading Comprehension at Grade VIII.4 of

SMP Negeri 3 Pekanbaru 
to read based on the title. As we know, predicting involves previewing the text to anticipate what will happen next. The thinking processes involved in predicting assist students in making meaning. Wood and Endres (2004:4) state that prediction involves getting use readers' prior knowledge to anticipate what may occur in a selection or text. These predictions help readers develop a purpose for reading, an essential instructional element that helps direct and motivate the reader to get started, stay on course, and proceed to the end of the reading assignment. In short, in order to make predictions about a text, students must have prior knowledge or experiences about the topic as well as a means, or a reason, to retrieve this latent information and knowledge.

Goodman in Burnes and Page (1991:37) points out that prediction refers to the reader's expectation of what meaning will be found on the page. Whereas, Block and Pressley (2001) state that making prediction, the readers are using the following processes: prior knowledge, thinking on a literal and inferential level, adding to their knowledge base, linking efferent and affective thinking processes, making connections, and filling the gaps in the author's writing. So that, making predictions while reading keeps the mind actively focused on the author's meaning and provides the reader with motivation and a purpose for reading.

Oczkus (2003:13) states that predicting is a strategy to improve comprehension which helps the reader set purposes for her or his reading. This strategy also increases students' interest and improves their understanding of the text. It means that before reading the text it will be better for the reader to predict the text because it can interest her or him to read and to know whether her or his prediction is correct or not. Then, she or he will read and try to comprehend the text completely.

The last phase is confirm which is done after the students make their prediction. In this phase, they have to confirm their previous predictions correct or incorrect. Burnes and Page (1991:38) state that in reading situation, prediction are confirmed or rejected on the same bases on which they were made. It is as if the reader asks if any prediction makes sense, sounds right, looks like what is on the page, and fits with the earlier part of the passage. Then, Duke and Pearson (2002:228) also state that an important aspect in the prediction process is comparing the prediction to the outcome in the actual text. He also states that without this aspect of prediction process, it become meaningless to improving the students' comprehension. It means that after making predicting, the reader will confirm whether her or his prediction correct or not, so that it can improve the reader's comprehension.

Briefly, each phase in IEPC strategy is able to make students become active participants in reading process, make them focus on the text, enhance their curiosity, and motivate the students to read the reading material. As a result, this strategy can improve the students' reading comprehension.

Related to the discription above, the researcher was encouraged to implement IEPC strategy during teaching and learning reading in order to solve the problems in her class. For this purpose, a classroom action research was carried out. The objectives of this research were to explain to what extent IEPC strategy could improve the reading

Using IEPC Strategy to Improve Students' Reading Comprehension at Grade VIII.4 of SMP Negeri 3 Pekanbaru 
comprehension at grade VIII.4 of SMP Negeri 3 Pekanbaru and the factors that influenced the changes of their reading comprehension.

\section{METHOD}

This study is kind of classroom action research. It is used to help teacher to improve the way of teaching in classroom. Kemmis et al (1998:5-10) state that action research is a form of collective self-reflective enquiry undertaken by participants in social justice of their own social or educational practices, conducted by the teachers or researchers to gain information about how well their particular schools execute their educational programs, how well teachers teach their students and how well their students. According to Gay (2000) action research is a process in which individual or several teachers collective evidence and make decisions about their own knowledge, performance, beliefs, and effect in order to understand and to improve them. $\mathrm{He}$ also says that action research is known as teacher research, teacher professional development, teacher as researcher, and teacher self-evaluation. Furthermore, the purpose of action research is to provide educational practitioners with new knowledge and resolve significant problems in classrooms and schools (Stringer, 2008:13). It means that the participants in action research are hoped to get more knowledge and understanding about a certain subject, so that they will be able to solve the problems. There are four fundamental aspects of action research namely; planning, action, observation, and reflection. In short, action research is done to give an improvement to the situation where the research is applied. It is commonly applied to solve some problems being faced by participants in the classrooms and schools. The participants of this research were the researcher, a collaborator and the students of grade VIII.4 of SMP Negeri 3 Pekanbaru in academic year 2009. The researcher decided to choose this class because she knew this class had lower ability in reading comprehension than other classes. The students of this class consists of 40 students; 19 males and 21 females.

The instruments of this research were a reading comprehension test, an observation sheet, field note, and interview. To analyze the quantitative data, the researcher evaluated and analyzed the students' reading comprehension test scores in order to know the significance of their progress before and after learning by using IEPC strategy. The test was taken at the end of each cycle. In other side, qualitative data was used to know factors influence the changes of students' learning participation through the use of IEPC strategy. The data was collected through observation sheet, field note, and interview. The procedure of this research followed the model of classroom action research. The model used cyclical process namely, plan, action, observation, and reflection.

\section{FINDINGS AND DISCUSSION}

The extent to which IEPC
strategy could improve
students, reading
comprehension at grade VIII.4
of SMP Negeri 3 Pekanbaru.

Using IEPC Strategy to Improve Students' Reading Comprehension at Grade VIII.4 of SMP Negeri 3 Pekanbaru 
After analyzing the data from students' reading comprehension test score, the researcher could show her findings from the result of the test in cycle 1,2 , and 3 . Based on the results during cycle 1 , cycle 2 , and cycle 3 conducted for twelve meetings, it was found that the scores of the students' reading comprehension in each indicator in cycle 1 was not yet satisfactory. Therefore, the process continued to cycle 2 ; in this cycle, students made some improvements but the average scores of each indicator in this cycle still could not achieve the minimum criteria achievement, so she continued to cycle 3 . In cycle 3, the data showed that students' scores of reading comprehension by using IEPC strategy in each indicator increased significantly. The average score of each indicator had reach the minimum criteria achievement. The difference between the improvement of students' comprehensionbefore and after implementing IEPC strategy can be seen in the following diagram:

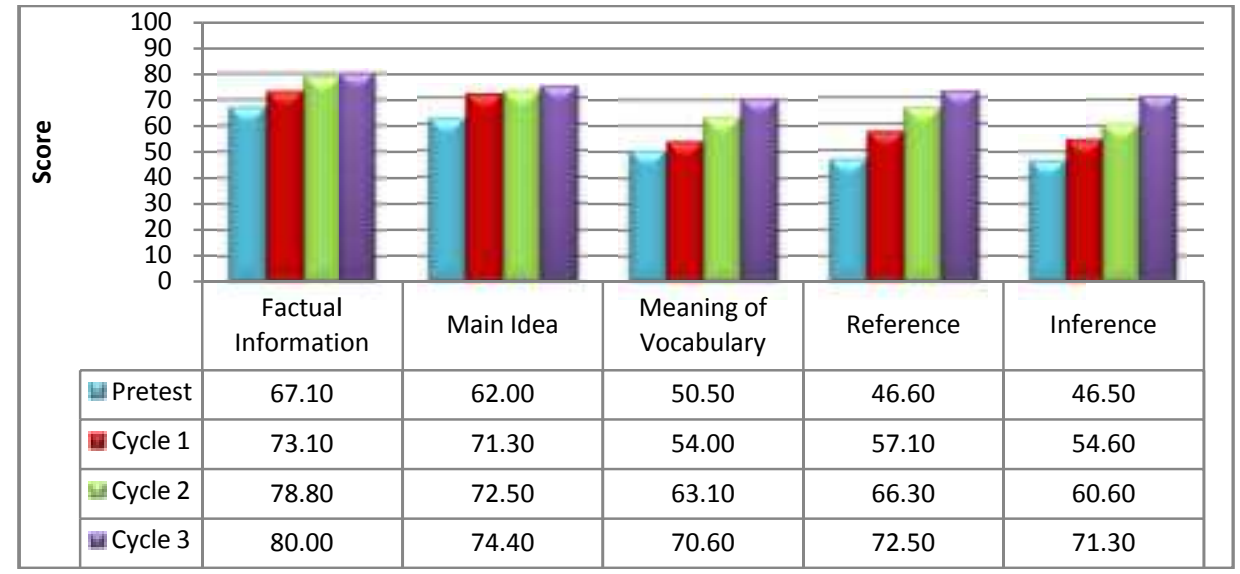

\section{Diagram 1. The Comparison of the Test Results of Each Indicator of Reading Comprehension in the Pre-test, Cycle 1, Cycle 2, and Cycle 3.}

The above diagram shows that all indicators of reading comprehension test are improving after using IEPC strategy.

The following diagram shows the improvement of students' average score of reading comprehension before using IEPC strategy during cycle 1 , cycle 2, and cycle 3 .

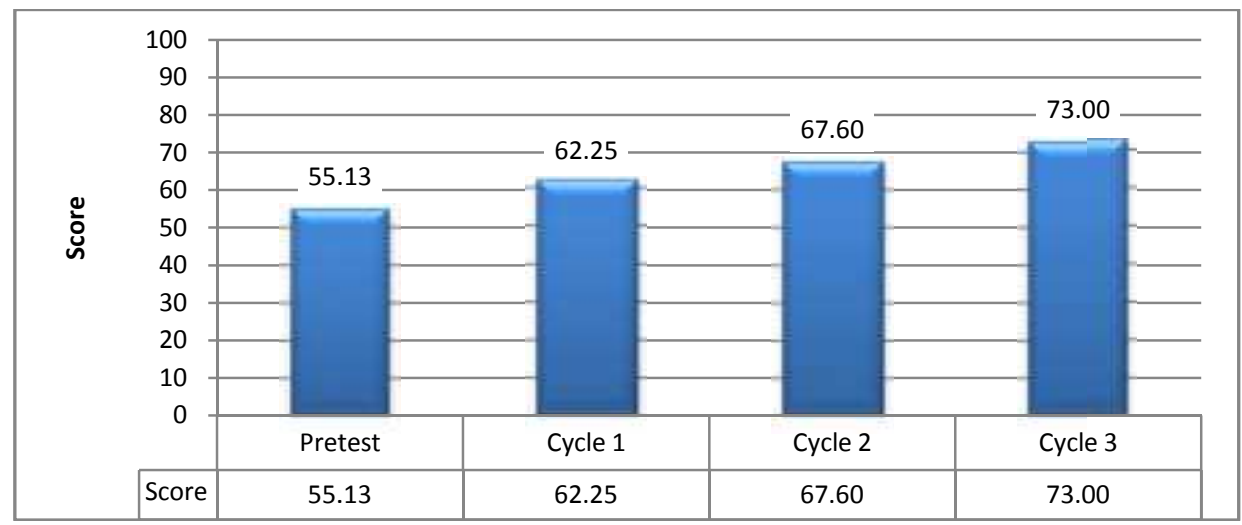




\section{Diagram 2. The Comparison of Students' Average Score of Reading Comprehension in the Pre-test, Cycle 1, Cycle 2, and Cycle 3.}

Diagram 2 shows that there is improvement on the average score in reading comprehension before and after implementing IEPC strategy in teaching reading. In fact, the average score of students' reading comprehension through the use of IEPC strategy in cycle 1, cycle 2 , and cycle 3 is better than before applying IEPC strategy. The researcher find that there is significant improvement to the students' scores of reading comprehension test from pre-test, Cycle 1,2 , and 3. The average score of the students' comprehension increase 7.12 points at the end of cycle 1 . The diagram shows, however, that the average score is not significantly increased. At the end of cycle 2, the average score of students' comprehension increases 12.47 points. In facts, eventhough there is improvement on the average score of the students' comprehension, the result is still can not reach the minimum criteria of achievement. Furthermore, at the end of cycle 3 the average score of students' reading comprehension increases 17.87 points. It means there is significant improvement which already reaches the minimum criteria of achievement at SMP Negeri 3 Pekanbaru. In addition, the results in cycle 3 showsthat $80 \%$ of the students reach the minimum criteria of achievement.

Based on the research findings in three cycles, it was discovered that the implementation of IEPC strategy could better improve the reading comprehension of grade VIII.4 of SMP Negeri 3 Pekanbaru. The findings were congruent with Moyer (2007) who found that IEPC strategy could improve students' motivation and reading comprehension. This statement is correct as the result of each cycle that had conducted by the researcher.

\section{b. The factors that influence the changes of students' reading comprehension by using IEPC strategy.}

After implementing IEPC
strategy in teaching reading
comprehension and having analyzed the
results obtained from observation
checklists, field notes, and interview, it
was found that there were some factors
that influenced the changes of students'
reading comprehension, i.e. teaching
material and media, classroom activity,
classroom management and lecturer's
approach.

\section{1) Teaching material and media}

Based on the result of interview, observation, and field notes, it was identified that reading material influenced the changes of students' reading comprehension. Most of he students were interesting in the reading material because the researcher explored the material from internet, newspaper, the other students' textbook which is appropriate with their level and relevant with the topic.

$$
\text { Interesting teaching }
$$

material and media used in teaching and learning process by using IEPC strategy makes students more motivate to study. This finding is line with Richard (2002) proposes that in teaching reading comprehension, the materials are a key component in most language pattern. In order to increase the students' 
comprehension, the teacher should know the appropriate materials for their students. Furthermore, the media used by the teacher to interact the students' attention. There are many medias that can be used in teaching and learning reading comprehension namely, pictures, cards, printed materials, LCD, etc. It is line with Harmer (2001) who says that most of students show an increased level of interest in learning language when they have a chance to see and involve in using the media.

\section{2) Classroom activity}

The second factors that influenced students' reading comprehension is the activity in IEPC strategy. Each phase of IEPC strategy helps and motivates students in improving their reading comprehension. The students become active participants during teaching and learning activity. This finding is line with Wood and Endress (2004) who state that IEPC strategy can motivate students to read and improve their comprehension.

\section{3) Classroom management.}

The next factors that influenced students' reading comprehension is classroom management. The ability of the teacher to control the class is very crucial. Moreover, they should be classified into group which sometimes were not appropriate for them. The students could work collaboratively when they felt comfortable with their group. Besides, the teacher needed to explain more detail to make students understand about activity in using IEPC strategy and all indicators of reading comprehension so that the process of teaching and learning could run as planning. It is congruent with Seken as quoted by Wastuti (2005) states that the roles of teacher in teaching reading are give brief explanation of certain key problems, to set the students' work on real situation, and help students to develop their own strategies for making sense of the text.

\section{4) Teacher's approach}

The last factor that influenced students' reading comprehension by using IEPC strategy is teacher's approach. Dealing with observation sheet, field notes and interview the teacher's approach was good enough because she coould adapt with the students. She scaffolded the students during teaching and learning process by checking the students have understood all instructions and done learning activities well. In addition, the teacher could give more attention and opportunities to the passive students to share their ideas. So that, all of the students become active participants. Furthermore, Crawley and Merritt (2009:124) state that 'the teacher's approach to teaching the structure of informational text improves both comprehension and recall of key text information".

As a final point, IEPC strategy could improve the effectiveness of teaching and learning process which is aimed to increase the students' reading 
comprehension. In addition, the implementation of IEPC strategy in learning reading comprehension could positively affect the students' reading comprehension.

\section{CONCLUSION}

After conducting this research in three cycles, it can be concluded that IEPC strategy can better improve the reading comprehension at grade VIII.4 of SMP Negeri 3 Pekanbaru. The improvement can be seen from the average score of reading comprehension test from pre-test, cycle 1 , cycle 2 , and cycle 3 . There were some factors which influenced the changes of students reading comprehension by using IEPC strategy; that is, teaching material and media, classroom activity, classroom management, and teacher's approach.

\section{REFERENCES}

Ahuja, Pramila andAhuja, G.C. 2001. How to Increase Reading Speed, Procedures and Practices $\left(4^{\text {th }}\right.$ Ed). New Delhi: Sterling Publisher Pvt.

Armbruster, B.B, Anderson, T.H, and Meyer, J.L.1990. The Framing Project: A Collaboration to Improve Content Area Reading Using Instructional Graphics (Tech.Rep). Urbana IL: University of Illinois, Center for the Study of Reading.

Block.C.C and Pressley. M. 2001. Comprehension Instruction: Research-based Best Practices. London: Guilford.

Burnes, D and Page, G. 1991. Insight and Strategies for Teaching
Reading. New York: Harcourt Brace Jovanich Group. Pty Limited

Crawley, S.J and Merritt, K. 2009. Remediating Reading Difficulties. Boston: McGraw-Hill.

Devine, T.G. 1987. Teaching Reading Comprehension from Teaching to Practice. Boston: Merril Publishing

Diptodadi, L. Veronica. 1992. Reading Strategies to improve comprehension in EFL. Jakarta: Teflin Journal.

Duke, N.K and Pearson, P.P. 2002. Effective Practices for Developing Reading Comprehension. London: International Reading Asscociation Inc.

Gambrell, L.B and Bales, R.J.1986. Mental Imagery and the Comprehension-Monitoring Performance of Fourth and Fifth Grade Poor Readers. Reading Research Quarterly, 21.454-464.

Gay, L. R. 2000. Educational Research for Analysis and Application (9th $E d)$. New Jersey: Pearson.

Grabe, S \& Sttaler F.L. 2002. Teaching and Researching Reading. London: Longman.

Harmer. 2001. The Practice of English Language Teaching (2nd ed). Completely Revised and Update. London: Longman

Kemmis, Stephen. 1998. The Action Research Planner (3rd ed). Victoria: Deakin University Press

Using IEPC Strategy to Improve Students' Reading Comprehension at Grade VIII.4 of SMP Negeri 3 Pekanbaru 
Kendeou and Broek, V.D. 2007. The Effects of Prior Knowledge and Text Structure on Comprehension Processes during Reading of Scientific Texts. Jurnal Memory and Cognition, 1567-1577. Springer-Verlag.

Moyer, Tara. 2007. What Activities can be implemented in the Classroom to increase Students' Motivation to Read.A journal. http://beryl.educ.psu.edu/pds_do wnload/2007InquiryProjects/Moy erTInquiry0607.pdf

Oczkus, D.L. 2003. Reciprocal Teaching at Work: Strategies for Improving Reading Comprehension. Newark, De: International Reading Association Inc.

Richard, Jack C. 2002. Curriculum Development in Language Teaching. New York: Cambridge University Press.

Stringer, Ernie. 2008. Action Research in Education (2nd Ed). New Jersey: Pearson.

Wastuti, Sri. 2005. The Effect of Collaboratiove Strategy Reading Toward the Second Year Students' Reading Comprehension Achievement at SLTP N 20 Pekanbaru. A Thesis. (Unpublished).

Wood, Karen. D. January 2002 • Volume 33 - Number 3 - Pages 47-54. Middle School Journal, Research into Practice. Aiding Comprehension with the Imagine, Elaborate, Predict, and Confirm (IEPC)Strategy.(www.nmsa.org/ Publications/MiddleSchoolJourn
al/Articles/January2002/Article9/ tabid/422/Default.aspx.)

Wood, K.D and Endres .C. December 1, 2004. Motivating Student interest with the Imagine, Elaborate and Confirm (IEPC) Strategy. The Teaching Reading Article. New York: Longman. 